Monika PŁaziak

Uniwersytet Pedagogiczny, Kraków, Polska • Pedagogical University of Cracow, Poland

ANNA IRENA SZYMAŃSKA

Uniwersytet Pedagogiczny, Kraków, Polska • Pedagogical University of Cracow, Poland

\title{
Sektor budowlany w Polsce ze szczególnym uwzględnieniem budownictwa mieszkaniowego oraz syłuacii mieszkaniowej w województwie małopolskim
}

\section{Construction Sector in Poland with Particular Reference to Housing in the Małopolska Region}

Streszczenie: W opracowaniu dokonano analizy stanu sektora budowlanego w Polsce w ujęciu całościowym i regionalnym, ze szczególnym uwzględnieniem województwa małopolskiego. Dodatkowy akcent położono na sytuację budownictwa mieszkaniowego. Analiza budownictwa mieszkaniowego dotyczyła lat 2006-2012, obejmujących okres bezpośrednio poprzedzający światowy kryzys gospodarczy, a także jego pierwsze fazy. W artykule stwierdzono opóźnione reagowanie sektora budowlanego na kryzys. Ponadto zauważono, iż kryzys dotknął różnych działów tego sektora w różnym stopniu. Najbardziej dotkliwy okazał się dla budownictwa mieszkaniowego. Mimo to w ciągu dwóch ostatnich dekad zaobserwowano w tym dziale korzystne tendencje dotyczące wzrostu liczby i powierzchni mieszkań oddawanych do użytkowania, przy czym zaznacza się tendencja do wzmożonej dynamiki oddawanych mieszkań na terenach dotychczas najsłabiej zainwestowanych w tym zakresie, zarówno w skali regionalnej, jak i lokalnej. Jednakże Polskę nadal charakteryzuje przepełnienie mieszkań ludnością, a województwo małopolskie plasuje się pod tym względem poniżej średniej krajowej.

\begin{abstract}
In the article the situation of the construction sector in Poland and the Małopolska Region is analysed. Particular emphasis is put on the situation in the field of housing. A detailed analysis concerning housing in the Małopolska Region concerned the years 2006-2012, covering the period just before the global economic crisis and during the crisis. The study found delayed response to the construction industry in crisis, as well as noted the fact that the crisis touched different areas of this sector and in varying degrees. The most acute it was for housing construction. However, over the past two decades in the field of housing the favourable trend in the increase in the number and surface area of completed dwellings for the use has been observed. Also, it has been observed that there is a tendency for increased dynamics of donation in housing - so far the least invested in both regional and local scale. However, Poland is characterised by the overcrowded dwellings and the Małopolska Region ranks in this respect below the national average.
\end{abstract}

Słowa kluczowe: budownictwo mieszkaniowe; sektor budowlany; województwo małopolskie Keywords: housing; construction sector; Małopolska Region

Otrzymano: 8 marca 2014

Received: 8 March 2014 
Zaakceptowano: 28 czerwca 2015

Accepted: 28 June 2015

\section{Sugerowana cytacja / Suggested citation:}

Szymańska, A., Płaziak, M. (2015). Sektor budowlany w Polsce ze szczególnym uwzględnieniem budownictwa mieszkaniowego oraz sytuacji mieszkaniowej w województwie małopolskim. Prace Komisji Geografii Przemystu Polskiego Towarzystwa Geograficznego, 29(2), 94-112.

\section{WSTĘP}

Budownictwo jest jednym z sektorów gospodarki podlegającym dynamicznym zmianom, a jednocześnie wywierającym istotny wpływ na rozwój całej polskiej gospodarki, choć nie w takim zakresie jak przemysł czy handel, ale w większym niż chociażby rolnictwo. W literaturze przedmiotu często konstatuje się, że sektor budowlany bardzo szybko, wraz z usługami finansowymi i przemysłem przetwórczym skierowanym na eksport, ucierpiał w pierwszej fazie światowego kryzysu ekonomicznego - w latach 2008-2009, a także że kryzys w szczególności uderzył właśnie w sektor budowlany (Gorzelak, 2009: 12, 32; Tarnawska, 2011: 156, 157). Jednocześnie kryzys w budownictwie wpływa negatywnie na działalność przemysłową, czyli przemysł metalurgiczny (produkcja stali zbrojeniowej), przemysł meblarski, przemysł chemiczny (np. produkcja dywanów i wykładzin), przemysł cementowy, przetwórstwo drewna, produkcję maszyn budowlanych (Gorzelak, 2009: 12).

Jednakże rozwój kryzysu finansowego i w konsekwencji recesja całej gospodarki nie przebiegają równocześnie w poszczególnych krajach świata, jak też różne sektory gospodarki i działy w różnym stopniu poddają się wahaniom kryzysowym. Gospodarki krajów strefy euro zostały dotknięte przez kryzys z opóźnieniem w stosunku do Stanów Zjednoczonych recesja w tej części świata rozpoczęła się pół roku później, dopiero w II kwartale 2008 roku. A nieco później kryzys dotarł do Polski. W pierwszej fazie kryzysu Polska, podobnie jak niektóre inne kraje rozwijające się, nie odczuła bezpośrednio jego skutków, gdyż początkowo wpływ turbulencji na światowych rynkach finansowych na gospodarkę krajową ograniczał się głównie do rynków kapitałowych (Rachwał, 2011: 99).

Zgodnie z powyższym autorki opracowania starały się zaakcentować fakt, że polski sektor budowlany zareagował co prawda na światowy kryzys ekonomiczny spadkiem produkcji budowlano-montażowej, lecz reakcja ta niekoniecznie była gwałtowna i szybka. Produkcja budowlano-montażowa w Polsce do 2012 roku była wspierana przez liczne inwestycje prowadzone w ramach polityki spójności i programów rządowych oraz przygotowań do Mistrzostw Europy w Piłce Nożnej Euro 2012 (remonty i budowy dróg, budowa boisk - tzw. orlików, a także innej infrastruktury technicznej i społecznej). Jeszcze w 2011 roku produkcja ta wykazywała charakter wzrostowy. Jej spadek w kolejnym roku dotyczył przede wszystkim dwóch obszarów: produkcji firm budowlanych specjalizujących się we wznoszeniu budynków oraz produkcji firm wykonujących specjalistyczne roboty budowlane. I to właśnie tam pojawiły się pierwsze symptomy kryzysu w budownictwie. Natomiast firmy budowlane realizujące kontrakty dotyczące inżynierii lądowej i wodnej odnotowały wówczas wzrost produkcji (Płaziak, 2013: 217). Faktycznie od 2005 do 2010 roku obserwowano w Polsce 
systematyczny wzrost udziału zamówień w sferze budowlanej w ogólnej liczbie i wartości zamówień publicznych (Kozik, Starzyk, 2011: 529). W połowie 2014 roku nadal notowano wzrost poziomu zrealizowanych robót w zakresie obiektów inżynierii lądowej i wodnej, ale również w zakresie budowlanych robót specjalistycznych. Spadek produkcji dotyczył podmiotów zajmujących się głównie wznoszeniem budynków (Dynamika produkcji..., 2014). Można zatem uznać, że ewentualny kryzys w polskim budownictwie dotyczy głównie dziedziny wznoszenia budynków. Do powyższych analiz dotyczących reakcji polskiej produkcji budowlano-montażowej na światowy kryzys oraz do określenia roli, jaką sektor budowlany odgrywa w Polskiej gospodarce, autorki opracowania wykorzystały dane statystyczne GUS (Bank Danych Lokalnych; Informacje bieżące, Roczne wskaźniki makroekonomiczne) oraz raporty dotyczące sytuacji budownictwa i rynku nieruchomości w Polsce (zwłaszcza raporty Domu Maklerskiego BDM S.A, jak również Narodowego Banku Polskiego).

Kolejnym celem opracowania była analiza sytuacji budownictwa mieszkaniowego w Polsce, ze szczególnym uwzględnieniem skali regionalnej i lokalnej. Weryfikacji poddano hipotezę, że zwiększona dynamika produkcji w budownictwie mieszkaniowym dotyczy obszarów o najniższym stopniu nasycenia powierzchnią mieszkaniową. Do analizy wykorzystano dane GUS dotyczące liczby i powierzchni mieszkań oddanych do użytkowania w Polsce w dwóch ostatnich dekadach oraz w województwie małopolskim w latach 2006-2012.

Opracowanie zostało uzupełnione o ocenę sytuacji mieszkaniowej w Polsce i województwie małopolskim, z odniesieniem do problemu przepełnienia polskich mieszkań w porównaniu z warunkami panującymi w pozostałych krajach Unii Europejskiej. Do oceny tej wykorzystano dane statystyczne GUS oraz raporty Eurostatu - Housing Europe Review 2011 i Housing Europe Review 2012.

\section{RoLA BUDOWNICTWA W POLSKIEJ GOSPODARCE ORAZ JEGO AKTUALNA SYTUACJA}

Budownictwo stanowi istotny element polskiej gospodarki. Zważywszy, że wartość dodana osiągnięta przez poszczególne sekcje polskiej gospodarki stanowi $88,8 \%$ produktu krajowego brutto, to dla samego budownictwa jest to udział spory, gdyż wynosi 5,8\%, czyli jest wyższy niż dla rolnictwa, leśnictwa, łowiectwa i rybactwa (3,4\%), choć znacznie niższy niż dla przemysłu (22\%) czy handlu wraz z naprawą pojazdów samochodowych $(17,1 \%)$. Udział budownictwa w tworzeniu polskiego PKB jest znaczący i znaczenie to rośnie. Świadczy o tym dodatnia dynamika wartości dodanej brutto osiągniętej przez budownictwo za lata 2000-2013, która wyniosła ok. $+43 \%$. Dla porównania, w przemyśle okazała się ujemna i wyniosła ok. $-35 \%$, przy czym dla wszystkich sektorów łącznie była dodatnia i osiągnęła blisko $57 \%$ (tab. 1).

Sytuacja w samym budownictwie nie jest aktualnie dobra. Za obiektywny wskaźnik opisujący kondycję rynku budowlanego uznać można dynamikę produkcji budowlano-montażowej. Z roku na rok notuje się dla Polski spadającą dynamikę tej produkcji, podobnie jak dla produkcji przemysłowej. Wyjątkowym rokiem, o szczególnie korzystnej dynamice, był 2011 (w przypadku produkcji przemysłowej - 2010). Niestety, w 2012 roku zaznaczyły się symptomy recesji, zanotowano wtedy dla produkcji budowlano-montażowej dynamikę ujemną (ryc. 1). 
Tab. 1. Udział sekcji PKD w tworzeniu PKB w Polsce w 2013 roku

\begin{tabular}{|l|c|c|c|}
\hline \multicolumn{1}{|c|}{ Sekcje PKD } & $\begin{array}{c}\text { Wartość dodana } \\
\text { brutto (ceny bieżące } \\
\text { w mln zł) }\end{array}$ & $\begin{array}{c}\text { Udział } \\
\text { w PKB* } \\
\text { (\%) }\end{array}$ & $\begin{array}{c}\text { Rok 2000 = 100 } \\
\text { (ceny stałe) }\end{array}$ \\
\hline wszystkie sektory łącznie & 1452499 & 88,8 & 156,8 \\
\hline rolnictwo, leśnictwo, łowiectwo i rybactwo & 55048 & 3,4 & 106,1 \\
\hline przemysł & 359254 & 22,0 & 64,6 \\
\hline budownictwo & 94930 & 5,8 & 143,1 \\
\hline $\begin{array}{l}\text { handel; naprawa pojazdów } \\
\text { samochodowych }\end{array}$ & 280215 & 17,1 & 147,9 \\
\hline transport i gospodarka magazynowa & 98424 & 6,0 & 162,9 \\
\hline zakwaterowanie i gastronomia & 17585 & 1,1 & 123,3 \\
\hline informacja i komunikacja & 50546 & 3,1 & 227,1 \\
\hline działalność finansowa i ubezpieczeniowa & 62110 & 3,8 & 168,5 \\
\hline obsługa rynku nieruchomości & 85481 & 5,2 & 122,3 \\
\hline $\begin{array}{l}\text { działalność profesjonalna, naukowa } \\
\text { i techniczna }\end{array}$ & 75698 & 4,6 & 155,3 \\
\hline administrowanie i działalność wspierająca & 29240 & 1,8 & 252,9 \\
\hline $\begin{array}{l}\text { administracja publiczna i obrona narodowa; } \\
\text { obowiązkowe zabezpieczenia społeczne }\end{array}$ & 77009 & 4,7 & 134,6 \\
\hline edukacja & 66846 & 4,1 & 113,0 \\
\hline opieka zdrowotna i pomoc społeczna & 55527 & 3,4 & 150,7 \\
\hline $\begin{array}{l}\text { działalność związana z kulturą, rozrywką } \\
\text { i rekreacją }\end{array}$ & 11173 & 0,7 & 101,4 \\
\hline pozostała działalność usługowa & 25617 & 1,6 & 117,5 \\
\hline $\begin{array}{l}\text { gospodarstwa domowe zatrudniające } \\
\text { pracowników oraz wytwarzające produkty } \\
\text { na własne potrzeby }\end{array}$ & 0,5 & 130,9 \\
\hline
\end{tabular}

* W 2013 r. PKB wyniósł 1635746 mln zł.

Źródło: opracowanie własne na podstawie danych GUS: Roczne wskaźniki makroekonomiczne

O ile w 2011 roku rynek budowlany w Polsce znajdował się w dobrej kondycji, co było bezpośrednio związane z realizacją inwestycji infrastrukturalnych finansowanych z Programu Operacyjnego Infrastruktura i Środowisko na lata 2007-2013, a także z organizacją Euro 2012, o tyle już w 2012 roku produkcja budowlano-montażowa zmalała (ryc. 2), co zapewne było opóźnionym efektem światowego kryzysu, jako że sektor budowlany z reguły reaguje na wahania światowej koniunktury nieco później niż inne sektory ze względu na długotrwałość i sezonowość prac budowlanych (Płaziak, Szymańska, 2014). 
Ryc. 1. Dynamika produkcji sprzedanej przemysłu oraz budowlano-montażowej w latach 2006-2012

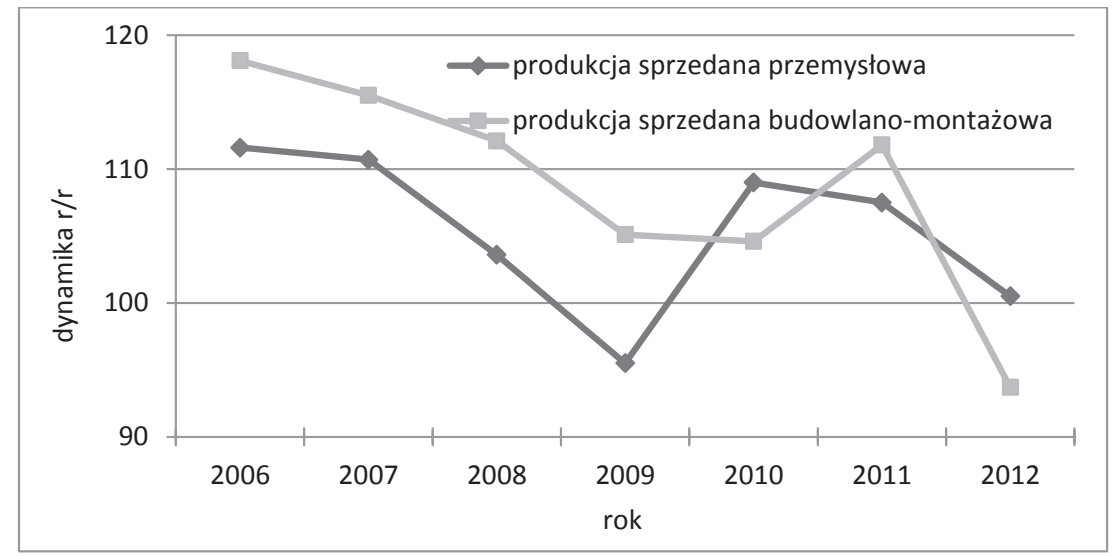

Źródło: opracowanie własne na podstawie danych GUS: Roczne wskaźniki makroekonomiczne

Ryc. 2. Produkcja sprzedana budowlano-montażowa w latach 2005-2013

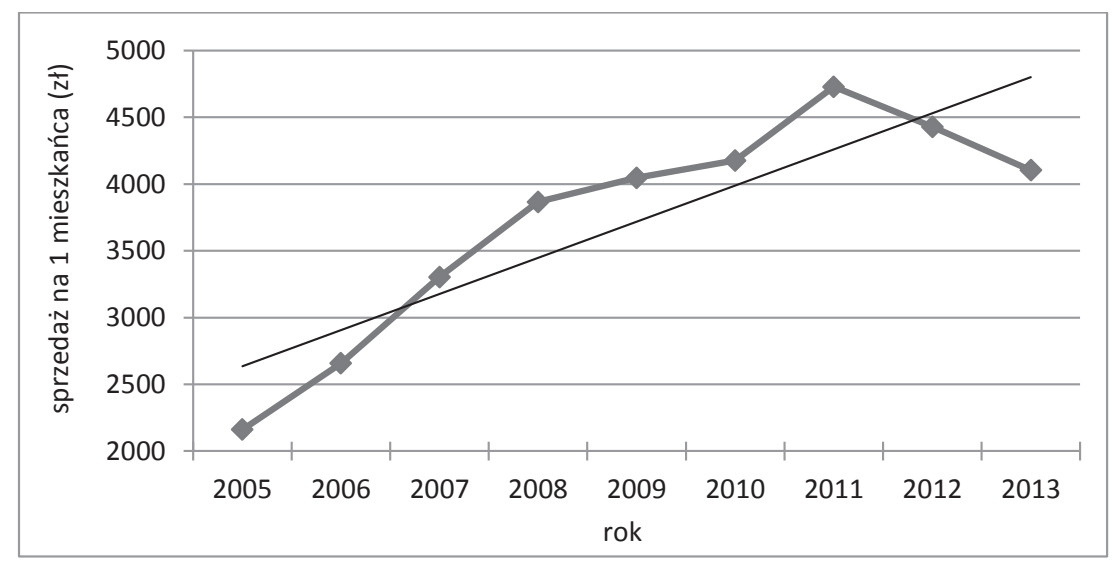

Źródło: opracowanie własne na podstawie Banku Danych Lokalnych GUS

W odróżnieniu od budownictwa, w sektorze przemysłowym, mimo spadającej rok po roku dynamiki produkcji, nie zanotowano w ostatnich latach (z wyjątkiem 2009 roku) dynamiki ujemnej, a produkcja sprzedana rośnie systematycznie od 2010 roku (ryc. 3).

Około 60\% produkcji budowlanej w Polsce generowane jest przez budownictwo pozakubaturowe (tab. 2), którego podstawę działalności stanowi budowa dróg, mostów oraz linii kolejowych (te trzy segmenty generują łącznie 34\% produkcji budowlanej w Polsce). Wydatki w tym obszarze finansowane są głównie (poza koncesjonowanymi odcinkami autostrad) ze środków budżetowych i unijnych. Ograniczenie wydatków na budowę dróg i autostrad po 2012 roku wpłynęło znacząco na spadek wartości rynku budowlanego w Polsce. Zmniejszenie wydatków na drogi i autostrady o 7,6 mld zł w 2013 roku względem poziomu 
z 2010 roku spowodowało skurczenie się rynku o ok. 9\%. Co prawda, w związku z nowymi inwestycjami w energetyce (rozpoczęcie faktycznej budowy nowych bloków energetycznych w elektrowniach w Opolu i Kozienicach) można spodziewać się pewnego uzupełnienia wspomnianej luki po zmniejszeniu się inwestycji infrastrukturalnych, jednak nie w aż tak znaczącym zakresie. Dodatkową wartość rynku mogą stworzyć bloki gazowe, jednakże są to inwestycje jednostkowo mniejsze niż bloki węglowe, a podmioty krajowe mają stosunkowo niskie kompetencje, jeśli chodzi o ich budowę (Budownictwo, 2014: 23).

Ryc. 3. Produkcja sprzedana przemysłowa w latach 2005-2012

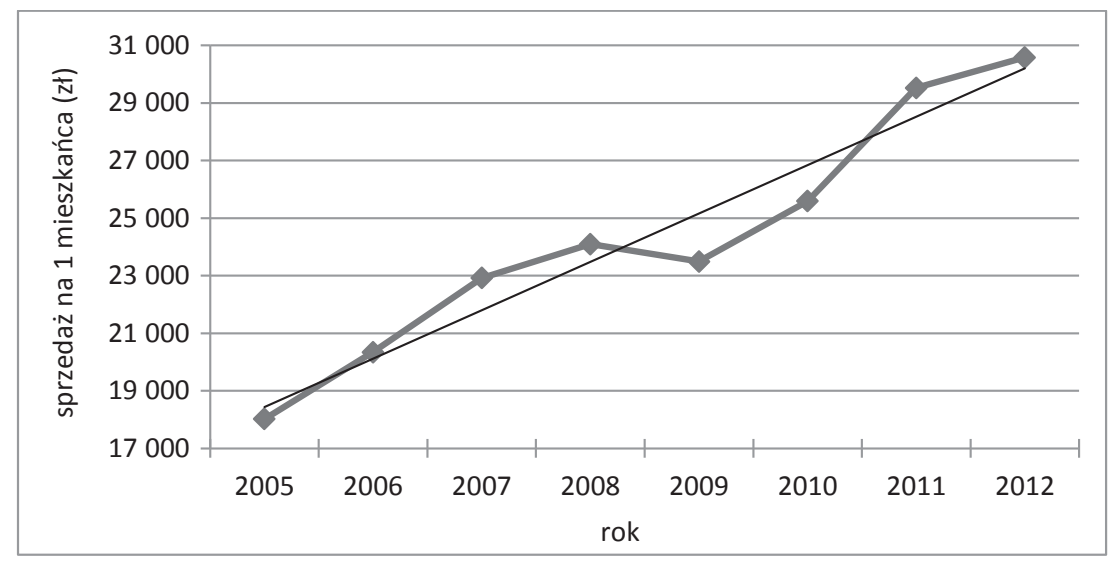

Źródło: opracowanie własne na podstawie Banku Danych Lokalnych GUS

Tab. 2. Struktura rynku budowlanego w Polsce w latach 2005-2010

\begin{tabular}{|l|r|r|r|r|r|r|}
\hline \multirow{2}{*}{ Produkcja budowlana w Polsce (w mld zł) } \\
\hline \multirow{2}{*}{ Rodzaje obiektów } & 2005 & 2006 & 2007 & 2008 & 2009 & 2010 \\
\hline ogółem & 42,0 & 50,8 & 66,7 & 77,2 & 80 & 81,7 \\
\hline budownictwo kubaturowe ogółem & 19,5 & 23 & 31,9 & 37,6 & 33,3 & 32,6 \\
\hline budynki mieszkalne & 5,8 & 6,8 & 10,7 & 13,4 & 11,5 & 9,6 \\
\hline obiekty inżynierii lądowej i wodnej & 22,5 & 27,8 & 34,8 & 39,6 & 46,6 & 49,1 \\
\hline dynamika łańcuchowa r/r & - & $21 \%$ & $31 \%$ & $16 \%$ & $4 \%$ & $2 \%$ \\
\hline ogółem & - & $18 \%$ & $38 \%$ & $18 \%$ & $-11 \%$ & $-2 \%$ \\
\hline budownictwo kubaturowe ogółem & - & $17 \%$ & $58 \%$ & $25 \%$ & $-14 \%$ & $-17 \%$ \\
\hline budynki mieszkalne & - & $24 \%$ & $25 \%$ & $14 \%$ & $18 \%$ & $5 \%$ \\
\hline obiekty inżynierii lądowej i wodnej & $100 \%$ & $100 \%$ & $100 \%$ & $100 \%$ & $100 \%$ & $100 \%$ \\
\hline struktura wg wielkości produkcji & $46 \%$ & $45 \%$ & $48 \%$ & $49 \%$ & $42 \%$ & $40 \%$ \\
\hline ogółem & $14 \%$ & $13 \%$ & $16 \%$ & $17 \%$ & $14 \%$ & $12 \%$ \\
\hline budownictwo kubaturowe ogółem & $54 \%$ & $55 \%$ & $52 \%$ & $51 \%$ & $58 \%$ & $60 \%$ \\
\hline (w tym: budynki mieszkalne)
\end{tabular}

Źródło: opracowanie własne na podstawie: Budownictwo, 2014: 23 
Budownictwo kubaturowe przyczynia się do pozostałych $40 \%$ produkcji budowlanej w Polsce, a należące do niego budownictwo mieszkaniowe - do ok. 12\% (tab. 2). W ostatnich kilkudziesięciu latach zanotowano w całym kraju zdecydowany wzrost ogólnej powierzchni mieszkaniowej oddanej do użytkowania. W okresie 1995-2013 wzrost ten wyniósł ok. 153\% (ryc. 4). Wzrost z 2003 roku związany był ze zwiększeniem popytu na mieszkania w okresie przed akcesją Polski do Unii Europejskiej, wynikającym prawdopodobnie z obawy kupujących przed gwałtownym wzrostem cen mieszkań po przystąpieniu do UE, co faktycznie nastąpiło. Natomiast wzrost powierzchni mieszkań oddanych do użytkowania w 2008 roku był efektem jeszcze pozytywnej koniunktury gospodarczej sprzed kryzysu. W okresie 20092011, jak już wspomniano, zaobserwowano zmniejszoną powierzchnię mieszkań oddanych do użytkowania, co było spowodowane przede wszystkim mniejszą aktywnością deweloperów, wynikającą bezpośrednio z wybuchu światowego kryzysu finansowego, który osłabił tempo wzrostu w sektorze budownictwa.

Ryc. 4. Powierzchnia mieszkań oddanych do użytkowania w Polsce w latach 1995-2013

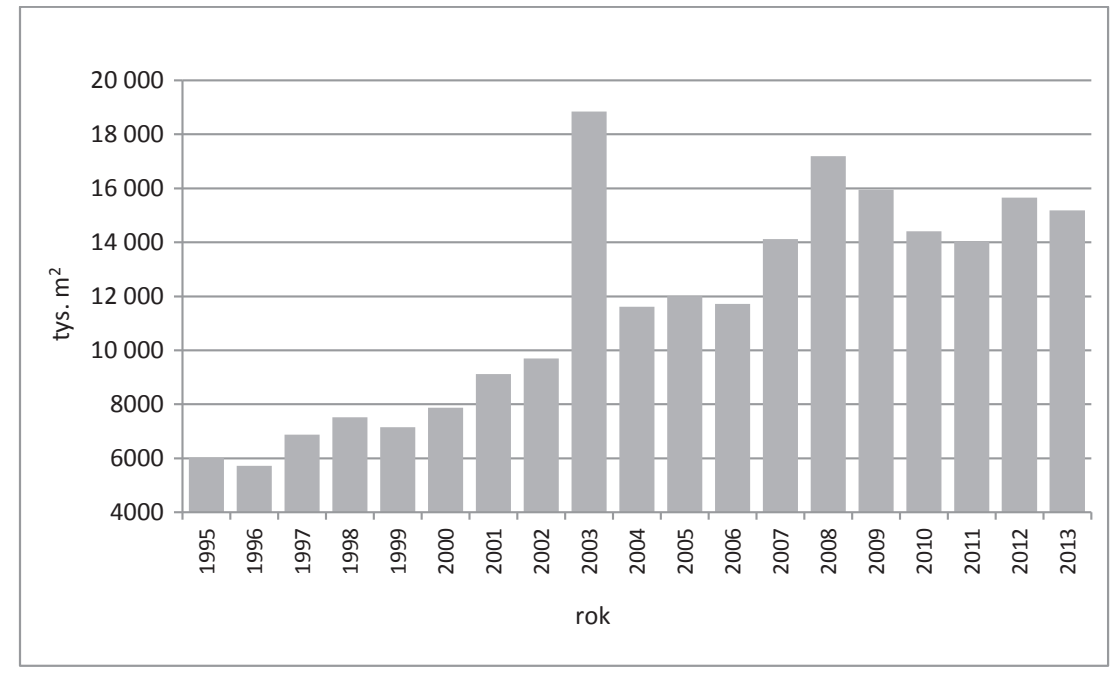

Źródło: opracowanie własne na podstawie Banku Danych Lokalnych GUS

Niestety, w latach 2009 i 2010 zaobserwowano duży spadek wartości inwestycji. Natomiast w 2011 roku nastąpiła poprawa. W okresie między trzecim kwartałem 2010 roku a drugim kwartałem 2011 roku w ofercie pojawiło się 37 tys. nowych mieszkań. Stanowiło to 5 tys. więcej niż w całym 2008 roku, kiedy obserwowano gwałtowny rozwój w tym segmencie (Budownictwo, 2014: 27). Faktycznie, w 2012 roku ponownie wzrosła powierzchnia mieszkań oddanych do użytkowania, spodziewano się nawet utrzymania tej tendencji (Płaziak, Szymańska, 2014), jednakże już w kolejnym roku (2013) powierzchnia ta okazała się mniejsza (ryc. 4). Należy przy tym zaznaczyć, że w 2013 roku liczby pozwoleń wydanych na budowę mieszkań oraz rozpoczętych inwestycji budownictwa mieszkaniowego były najniższe od 2006 roku (Raport o sytuacji..., 2014). 
Tab. 3. Pracujący według sekcji PKD w 2011 roku

\begin{tabular}{|l|c|c|}
\hline \multicolumn{1}{|c|}{ Sekcje PKD } & Pracujący (w tys.) & Udział (w \%) \\
\hline wszystkie sekcje & 14232,6 & 100,0 \\
\hline rolnictwo, leśnictwo, łowiectwo i rybactwo & 2376,7 & 16,7 \\
\hline górnictwo i wydobywanie & 175,6 & 1,2 \\
\hline przetwórstwo przemysłowe & 2443,6 & 17,2 \\
\hline $\begin{array}{l}\text { wytwarzanie i zaopatrywanie w energię elektryczną, gaz, } \\
\text { parę wodną i gorącą wodę }\end{array}$ & 152,8 & 1,1 \\
\hline $\begin{array}{l}\text { dostawa wody, gospodarowanie ściekami i odpadami, } \\
\text { rekultywacja }\end{array}$ & 143,3 & 1,0 \\
\hline budownictwo & 909,2 & 6,4 \\
\hline handel; naprawa pojazdów samochodowych & 2158,8 & 15,2 \\
\hline transport i gospodarka magazynowa & 727,9 & 5,1 \\
\hline zakwaterowanie i gastronomia & 237,5 & 1,7 \\
\hline informacja i komunikacja & 249,4 & 1,8 \\
\hline działalność finansowa i ubezpieczeniowa & 346,3 & 2,4 \\
\hline obsługa rynku nieruchomości & 198,2 & 1,4 \\
\hline działalność profesjonalna, naukowa i techniczna & 518,2 & 3,6 \\
\hline administrowanie i działalność wspierająca & 413,9 & 2,9 \\
\hline $\begin{array}{l}\text { administracja publiczna i obrona narodowa; } \\
\text { obowiązkowe zabezpieczenia społeczne }\end{array}$ & 951,9 & 6,7 \\
\hline edukacja & 1084,7 & 7,6 \\
\hline opieka zdrowotna i pomoc społeczna & 775,4 & 5,4 \\
\hline działalność związana z kulturą, rozrywką i rekreacją & 153,3 & 1,1 \\
\hline pozostała działalność usługowa & 215,9 & 1,5 \\
\hline
\end{tabular}

Źródło: opracowanie własne na podstawie: Rocznika statystycznego pracy 2012 (2014: 123)

Jak podkreślają analitycy rynku nieruchomości mieszkaniowych w Polsce, aktualnie sytuacja na rynku, zwłaszcza pierwotnym, uznawana jest za stabilną. W 2013 roku liczba gotowych mieszkań deweloperskich oczekujących na sprzedaż zmniejszyła się, osiągając poziom, który mógł zostać sprzedany w okresie ok. czwartego kwartału, a taki poziom przyjmowany jest na rynku pierwotnym za wyznacznik równowagi. Ponadto średnie ceny metra kwadratowego oferowanych mieszkań, zarówno na rynku pierwotnym, jak i wtórnym, znajdują się na w miarę stałym poziomie.

Jak wiadomo, jednym z ważnych czynników determinujących popyt na mieszkania są kredyty mieszkaniowe i ich dostępność. W 2013 roku wzrosła liczba i wartość złotowych kredytów mieszkaniowych, a w wyniku tego faktu zwiększył się także stan kredytów mieszkaniowych ogółem. Począwszy od 2011 roku ograniczona została kumulacja ryzyka związanego z kredytami walutowymi. W listopadzie 2013 roku, po raz pierwszy od 2002 roku, udział kredytów złotowych przekroczył 50\% całego portfela kredytów mieszkaniowych ( $R a-$ port o sytuacji..., 2014).

Trzeba zaznaczyć, że w 2012 roku zakończył się program „Rodzina na swoim”, czyli w 2013 roku zabrakło rządowego programu wsparcia nabywania mieszkań, co wpłynęło na osłabienie popytu. W 2014 roku wszedł w życie nowy (modyfikowany i krytykowany) 
program „Mieszkanie dla młodych”, który może generować dodatkowy, kilkuprocentowy popyt na mieszkania.

Omawiając rolę, jaką odgrywa budownictwo w tworzeniu gospodarki narodowej, należy podkreślić, że stanowi ono ważny rynek pracy - skupia ponad 6,4\% zatrudnionych we wszystkich sektorach gospodarki. Choć oczywiście nie jest to rynek tak znaczący, jak w przypadku przemysłu, rolnictwa czy handlu. Dla porównania, w przetwórstwie przemysłowym pracuje 17,2\% ogółu pracujących, w rolnictwie, leśnictwie, łowiectwie i rybactwie - 16,7\%, natomiast $w$ handlu wraz z naprawą pojazdów samochodowych - 15,2\% (tab. 3). Budownictwo podlega silnym rocznym wahaniom udziału pracujących. Powodem tego faktu jest duże rozdrobnienie firm budowlanych - znaczny udział niewielkich podmiotów gospodarczych, które są szczególnie podatne na zmiany koniunkturalne w całej gospodarce. W sektorze budowlanym korzystny wzrost udziału pracujących notowano w latach 2009-2011 (ok. 4\%), przy czym dla roku 2012 stwierdzono już ubytek wynoszący -0,2\% (Badanie ankietowe rynku pracy, 2014: 10).

\section{Sytuacja budownictwa mieszkaniowego w Polsce, ze szczególnym UWZGLĘDNIENIEM WOJEWÓDZTWA MAŁOPOLSKIEGO}

Poniżej zaprezentowano analizę stanu i dynamiki budownictwa mieszkaniowego dla Polski oraz dla województwa małopolskiego. Analiza objęła lata 2006 i 2012, czyli odpowiadające okresowi tuż sprzed kryzysu ekonomicznego i samego kryzysu. Sytuację budownictwa mieszkaniowego w Polsce oraz w województwie małopolskim określono poprzez liczbę oddanych mieszkań do użytkowania na 1000 mieszkańców (na podstawie danych GUS).

Ryc. 5. Liczba mieszkań oddanych do użytkowania na 1000 mieszkańców w Polsce w latach 2006-2012

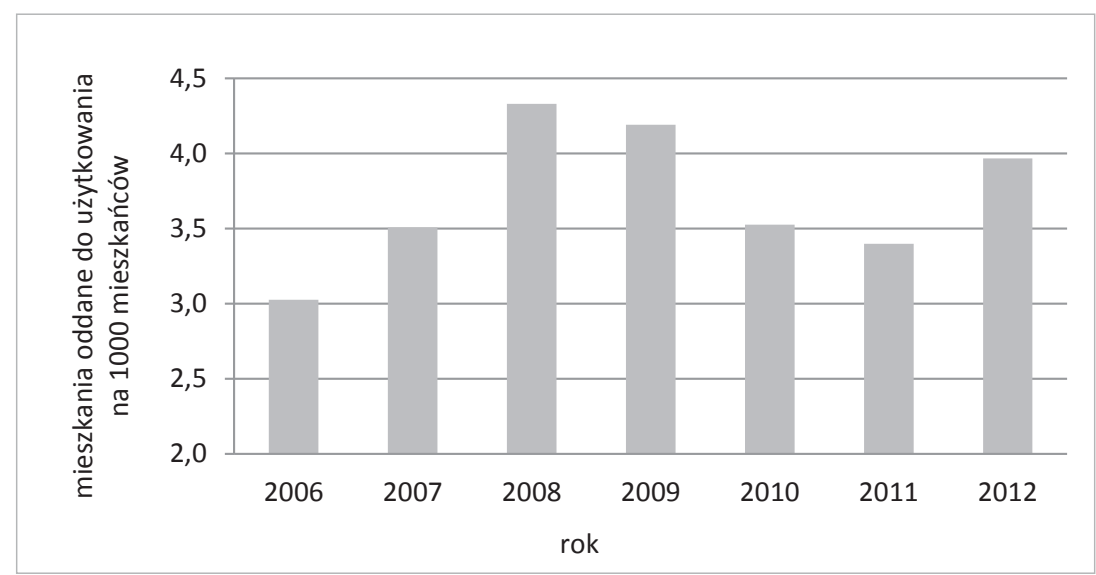

Źródło: opracowanie własne na podstawie Banku Danych Lokalnych GUS

W badanym okresie sytuacja budownictwa mieszkaniowego, mierzona wspomnianym wskaźnikiem, była dla Polski relatywnie korzystna, zarówno dla roku wyjściowego - 2006, 
jak też dla roku 2012, zamykającego badany okres, i wykazywała tendencję wzrostową. Wartość wskaźnika dla Polski wyniosła bowiem w latach 2006 i 2012 odpowiednio: 3,0 i 4,0; a w ujęciu dynamicznym w okresie 2006-2012 zanotowano wzrost liczby mieszkań oddanych do użytkowania o 32,6\% (tab. 4, ryc. 5). Dla porównania, wg badań prowadzonych przez autorki, w Czechach w tym samym okresie zanotowano dynamikę ujemną, wynoszącą $-2,4 \%$ (Płaziak, Szymańska, 2014: 55).

Tab. 4. Dynamika mieszkań oddanych do użytkowania w Polsce w latach 2006-2012

\begin{tabular}{|l|r|c|c|c|c|}
\hline Województwo & $\begin{array}{c}\text { Liczba } \\
\text { mieszkań } \\
\text { oddanych do } \\
\text { użytkowania } \\
\text { w 2006 r. }\end{array}$ & $\begin{array}{c}\text { Liczba } \\
\text { mieszkań } \\
\text { oddanych do } \\
\text { użytkowania } \\
\text { w 2012 r. }\end{array}$ & $\begin{array}{c}\text { Liczba } \\
\text { mieszkań } \\
\text { oddanych do } \\
\text { użytkowania } \\
2006=100\end{array}$ & $\begin{array}{c}\text { Liczba } \\
\text { mieszkań } \\
\text { oddanych do } \\
\text { użytkowania } \\
\text { na 1000 } \\
\text { mieszkańców } \\
\text { w 2006 r. }\end{array}$ & $\begin{array}{c}\text { Liczba } \\
\text { mieszkán } \\
\text { oddanych do } \\
\text { użytkowania } \\
\text { na 1000 } \\
\text { mieszkańców } \\
\text { w 2012 r. }\end{array}$ \\
\hline dolnośląskie & 9167 & 15028 & 163,9 & 3,2 & 5,2 \\
\hline kujawsko-pomorskie & 5006 & 6358 & 127,0 & 2,4 & 3,0 \\
\hline lubelskie & 4780 & 7190 & 150,4 & 2,2 & 3,3 \\
\hline lubuskie & 2918 & 3169 & 108,6 & 2,9 & 3,1 \\
\hline łódzkie & 4868 & 8019 & 164,7 & 1,9 & 3,2 \\
\hline małopolskie & 27090 & 30554 & 112,8 & 5,2 & 4,6 \\
\hline mazowieckie & 1338 & 1820 & 136,0 & 1,3 & 1,8 \\
\hline opolskie & 4652 & 6526 & 140,3 & 2,2 & 3,1 \\
\hline podkarpackie & 3036 & 4525 & 149,0 & 2,5 & 3,8 \\
\hline podlaskie & 10018 & 14194 & 141,7 & 4,5 & 6,2 \\
\hline pomorskie & 8325 & 9744 & 117,0 & 1,8 & 2,1 \\
\hline śląskie & 1614 & 3097 & 191,9 & 1,3 & 2,4 \\
\hline świętokrzyskie & 4469 & 5496 & 123,0 & 3,1 & 3,8 \\
\hline warmińsko-mazurskie & 10549 & 14811 & 140,4 & 3,1 & 4,3 \\
\hline wielkopolskie & 5118 & 7079 & 138,3 & 3,0 & 4,1 \\
\hline zachodniopomorskie & 115353 & 152904 & 132,6 & 3,0 & 4,0 \\
\hline Polska & & & & & \\
\hline
\end{tabular}

Źródło: opracowanie własne na podstawie Banku Danych Lokalnych GUS

Należy zauważyć, że dla Polski stwierdzono wyższą dynamikę liczby oddanych do użytkowania mieszkań w tych regionach, które w roku wyjściowym analizowanego okresu miały relatywnie niskie wartości wskaźnika liczby oddanych mieszkań na 1000 ludności - zaznaczyła się tam swojego rodzaju kompensacja niedoborów mieszkań, zwłaszcza w odniesieniu do województw świętokrzyskiego, łódzkiego, dolnośląskiego i podlaskiego (tab. 4). Dla województwa małopolskiego wartości wskaźnika liczby oddanych mieszkań na 1000 mieszkańców okazały się zdecydowanie wyższe od średniej krajowej, odpowiednio: 3,8 i 4,6; w ujęciu dynamicznym tendencja była wzrostowa, jednakże niższa od średniej krajowej i wyniosła 23,3\% (tab. 4). 
W ujęciu wewnątrzregionalnym opisana wyżej prawidłowość, dotycząca kompensacji niedoboru na rynku mieszkaniowym poprzez wzmożoną dynamikę na obszarach o najniższych wartościach wskaźnika liczby oddanych mieszkań do użytkowania na 1000 mieszkańców w roku wyjściowym 2006, widoczna jest wyraźniej w odniesieniu do mniejszych jednostek terytorialnych, czyli powiatów. W przypadku województwa małopolskiego powiaty o niskich wartościach wyjściowych wskaźnika uzyskały wysoką dynamikę. Z jednej strony były to powiaty typowo wiejskie, względnie oddalone od dużego miasta, jak chociażby powiat o najwyższej w województwie dynamice: miechowski $(326,7 \%)$ czy nowosądecki (176,2\%), bocheński (107,1\%), dąbrowski (niemal 93,6\%), z drugiej zaś - te bliskie głównego miasta w województwie - Krakowa, zwłaszcza powiat wielicki (107,3\%) (tab. 5, ryc. 6).

Tab. 5. Dynamika mieszkań oddanych do użytkowania w województwie małopolskim w latach 2006-2012

\begin{tabular}{|l|c|c|c|c|c|}
\hline \multicolumn{1}{|c|}{ Powiat } & $\begin{array}{c}\text { Liczba } \\
\text { mieszkań } \\
\text { oddanych do } \\
\text { użytkowani } \\
\text { w 2006 r. }\end{array}$ & $\begin{array}{c}\text { Liczba } \\
\text { mieszkań } \\
\text { oddanych do } \\
\text { użytkowania } \\
\text { W 2012 r. }\end{array}$ & $\begin{array}{c}\text { Liczba } \\
\text { mieszkán } \\
\text { oddanych do } \\
\text { użytkowania } \\
2006=100\end{array}$ & $\begin{array}{c}\text { Liczba } \\
\text { mieszkań } \\
\text { oddanych do } \\
\text { użytkowania } \\
\text { na 1000 } \\
\text { mieszkańców } \\
\text { w 2006 r. }\end{array}$ & $\begin{array}{c}\text { Liczba } \\
\text { mieszkań } \\
\text { oddanych do } \\
\text { użytkowania } \\
\text { na 1000 } \\
\text { mieszkańców } \\
\text { w 2012 r. }\end{array}$ \\
\hline chrzanowski & 192 & 197 & 102,6 & 1,5 & 1,5 \\
\hline oświęcimski & 370 & 380 & 102,7 & 2,4 & 2,5 \\
\hline Kraków & 6612 & 6824 & 103,2 & 8,7 & 9,0 \\
\hline wadowicki & 365 & 397 & 108,8 & 2,4 & 2,5 \\
\hline gorlicki & 222 & 262 & 118,0 & 2,1 & 2,4 \\
\hline tatrzański & 235 & 278 & 118,3 & 3,6 & 4,1 \\
\hline nowotarski & 395 & 488 & 123,5 & 2,2 & 2,6 \\
\hline olkuski & 207 & 267 & 129,0 & 1,8 & 2,3 \\
\hline suski & 265 & 351 & 132,5 & 3,2 & 4,2 \\
\hline brzeski & 201 & 268 & 133,3 & 2,2 & 2,9 \\
\hline Tarnów & 333 & 449 & 134,8 & 2,8 & 4,0 \\
\hline krakowski & 895 & 1231 & 137,5 & 3,6 & 4,7 \\
\hline proszowicki & 53 & 73 & 137,7 & 1,2 & 1,7 \\
\hline Nowy Sącz & 246 & 341 & 138,6 & 2,9 & 4,1 \\
\hline limanowski & 207 & 315 & 152,2 & 1,7 & 2,5 \\
\hline myślenicki & 290 & 448 & 154,5 & 2,5 & 3,6 \\
\hline tarnowski & 417 & 681 & 163,3 & 2,2 & 3,4 \\
\hline dąbrowski & 78 & 151 & 193,6 & 1,3 & 2,5 \\
\hline bocheński & 196 & 406 & 207,1 & 1,9 & 3,9 \\
\hline wielicki & 384 & 796 & 207,3 & 3,6 & 6,8 \\
\hline nowosądecki & 227 & 627 & 276,2 & 1,1 & 3,0 \\
\hline miechowski & 15 & 64 & 426,7 & 0,3 & 1,3 \\
\hline województwo \\
małopolskie & 12405 & 15294 & 123,3 & 3,8 & 4,6 \\
\hline
\end{tabular}

Źródło: opracowanie własne na podstawie Banku Danych Lokalnych GUS 
Ryc. 6. Dynamika liczby mieszkań oddanych do użytkowania w województwie małopolskim wg powiatów w latach 2006-2012

\section{Liczba mieszkań oddanych do użytkowania}
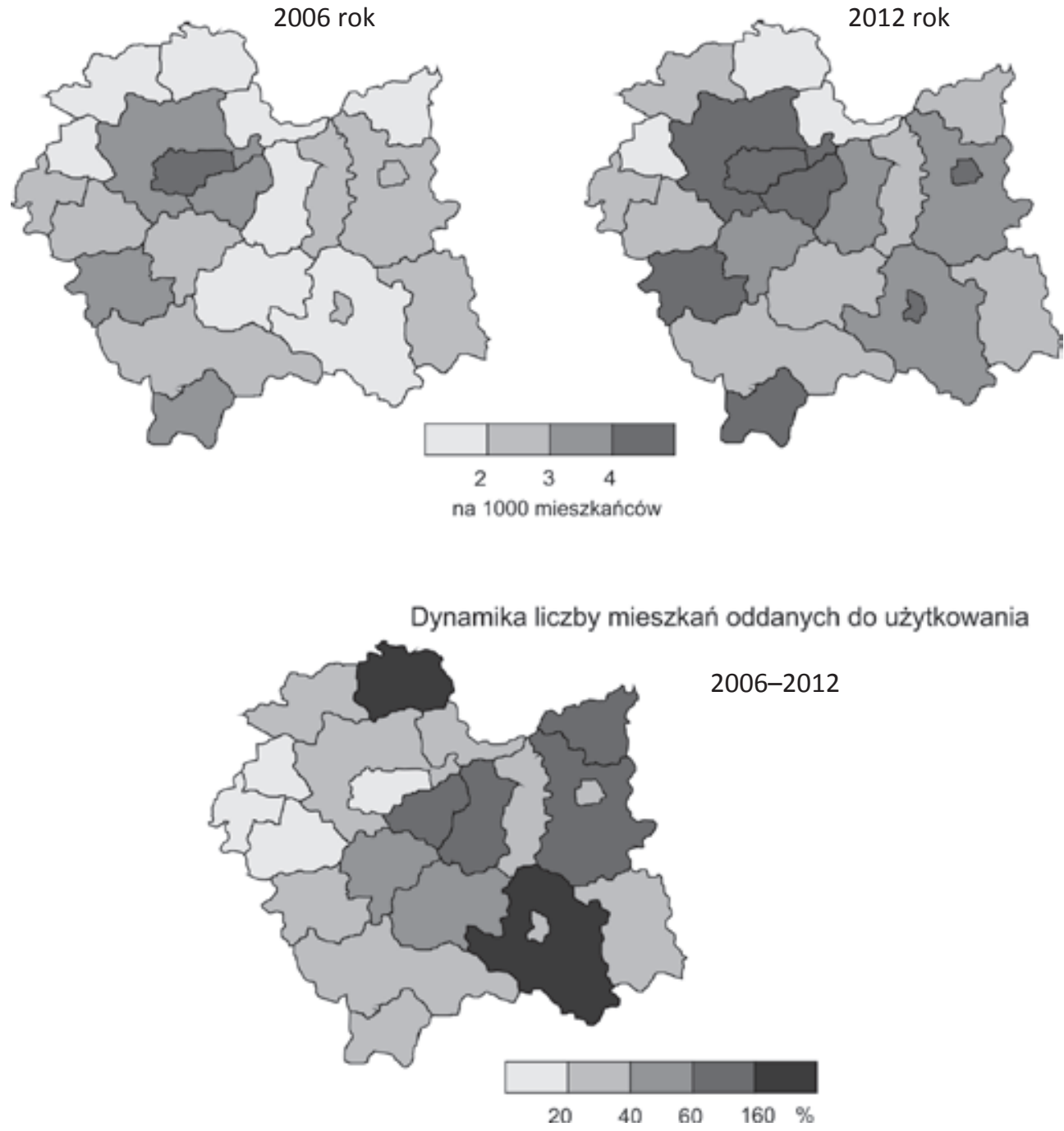

Źródło: opracowanie własne na podstawie Banku Danych Lokalnych GUS

Reasumując powyższą analizę, województwo małopolskie w badanym okresie 20062012 odzwierciedlało ogólnopolską tendencję wzrostową dynamiki mieszkań oddanych do użytkowania, choć na niższym poziomie. Zauważono zróżnicowanie przestrzenne intensywności tej tendencji - wyższa dynamika dotyczyła zwłaszcza powiatów o relatywnie 
niskim poziomie wyjściowym wskaźnika liczby oddanych mieszkań na 1000 mieszkańców, jak również powiatów znajdujących się w najbliższym sąsiedztwie największych ośrodków miejskich regionu, czyli Krakowa, Tarnowa i Nowego Sącza.

\section{Sytuacja MieszKaniowa w Polsce i WoJewÓDZTWIE MaŁopolskim}

Polskę na tle pozostałych krajów Unii Europejskiej charakteryzuje relatywnie niski standard mieszkaniowy, wyrażony chociażby liczbą mieszkań przypadającą na 1000 osób. Wskaźnik ten dla naszego kraju, chociaż systematycznie rośnie, wynosi aktualnie niespełna 360, podczas gdy dla wielu krajów Europy Zachodniej - ok. 500. Polskie mieszkania są mniejsze i przeludnione. Według badań Eurostatu szacuje się, że w przeludnionych mieszkaniach żyje w Polsce blisko 50\% ludności - podobną wartość wskaźnika spośród EU 27 mają Litwa, Bułgaria i Węgry, a gorszą jedynie Łotwa i Rumunia, przy średniej dla wszystkich państw unijnych wynoszącej niespełna 18\% (Housing Europe Review, 2011, 2012). Niemniej sytuacja w tym zakresie w Polsce systematycznie się poprawia. W ostatniej dekadzie liczba mieszkań przypadająca na 1000 mieszkańców wzrosła z 330 do wspomnianych 360 (ryc. 7).

Ryc. 7. Liczba mieszkań na 1000 mieszkańców w Polsce w latach 2003-2013

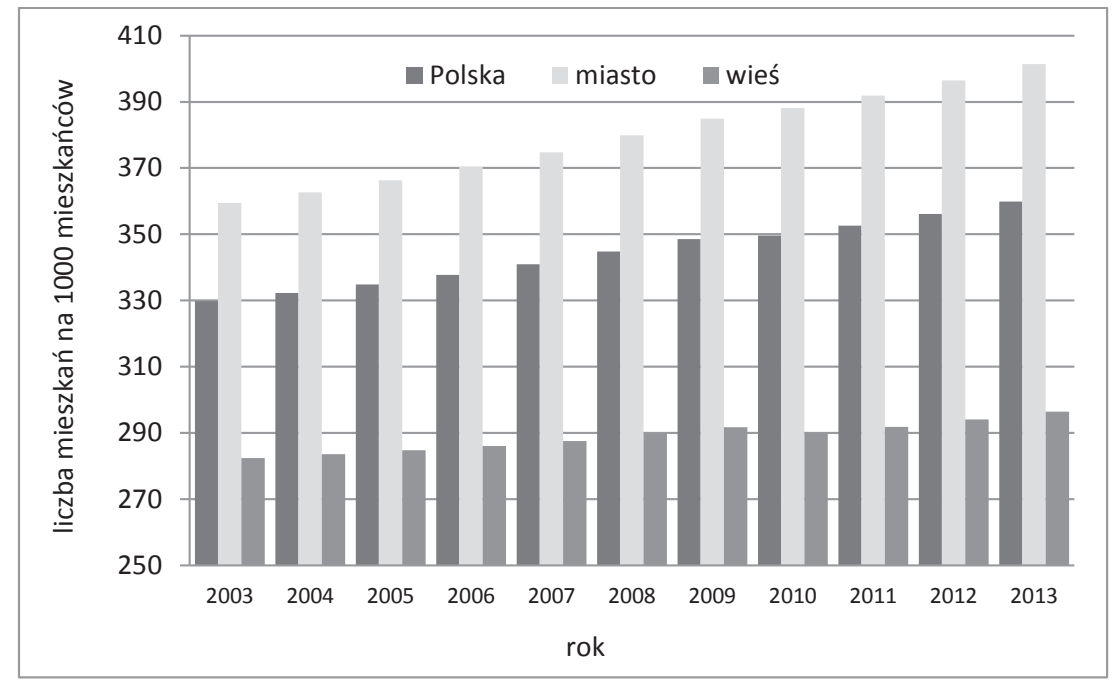

Źródło: opracowanie własne na podstawie Banku Danych Lokalnych GUS

Wskaźnik liczby mieszkań na 1000 mieszkańców inaczej kształtuje się na terenach miejskich, gdzie duży udział stanowią mieszkania w zabudowie wielorodzinnej, a inaczej na terenach wiejskich, dla których jest wyższy, ponieważ dominuje tam budownictwo jednorodzinne. Stąd lepszym wskaźnikiem obrazującym rzeczywiste warunki mieszkaniowe dotyczące stopnia przepełnienia mieszkań jest przeciętna powierzchnia użytkowa mieszkania przypadająca na osobę. Oczywiście i w tym przypadku wskaźnik pokazuje korzystniejsze 
wartości dla terenów wiejskich, jednakże różnica miasto-wieś jest w tym zakresie mniej widoczna i ciągle się zmniejsza (ryc. 8).

Ryc. 8. Przeciętna powierzchnia użytkowa mieszkania przypadająca na osobę w Polsce w latach 2002-2013

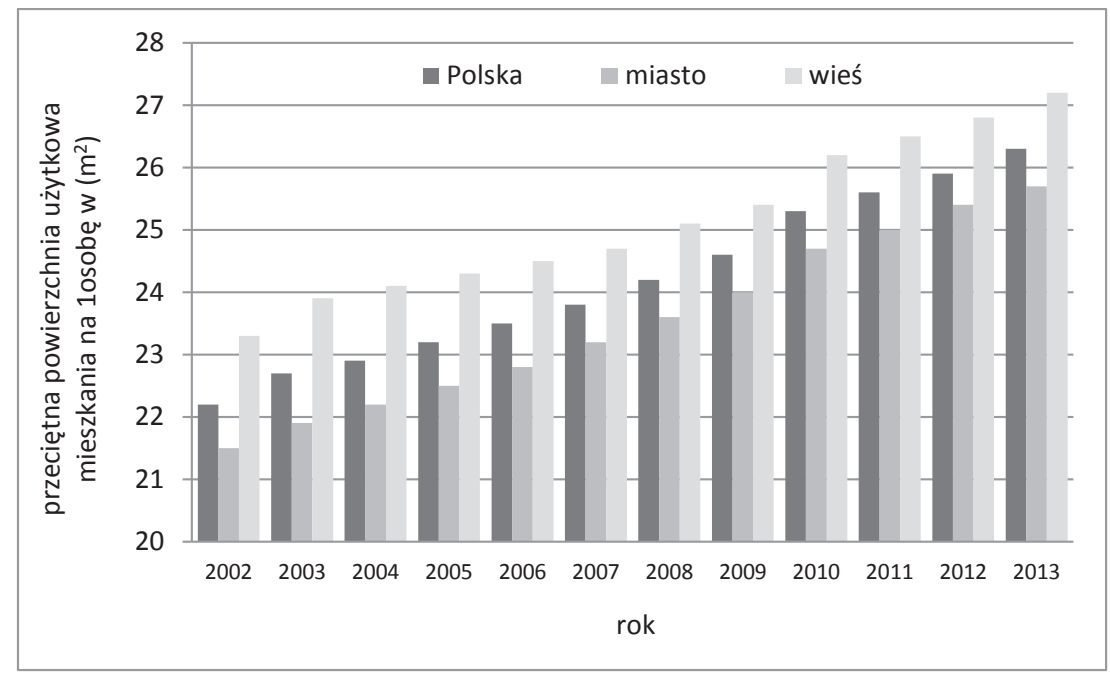

Źródło: opracowanie własne na podstawie Banku Danych Lokalnych GUS

Ryc. 9. Przeciętna powierzchnia użytkowa 1 mieszkania oddanego do użytkowania w Polsce w latach 2002-2013

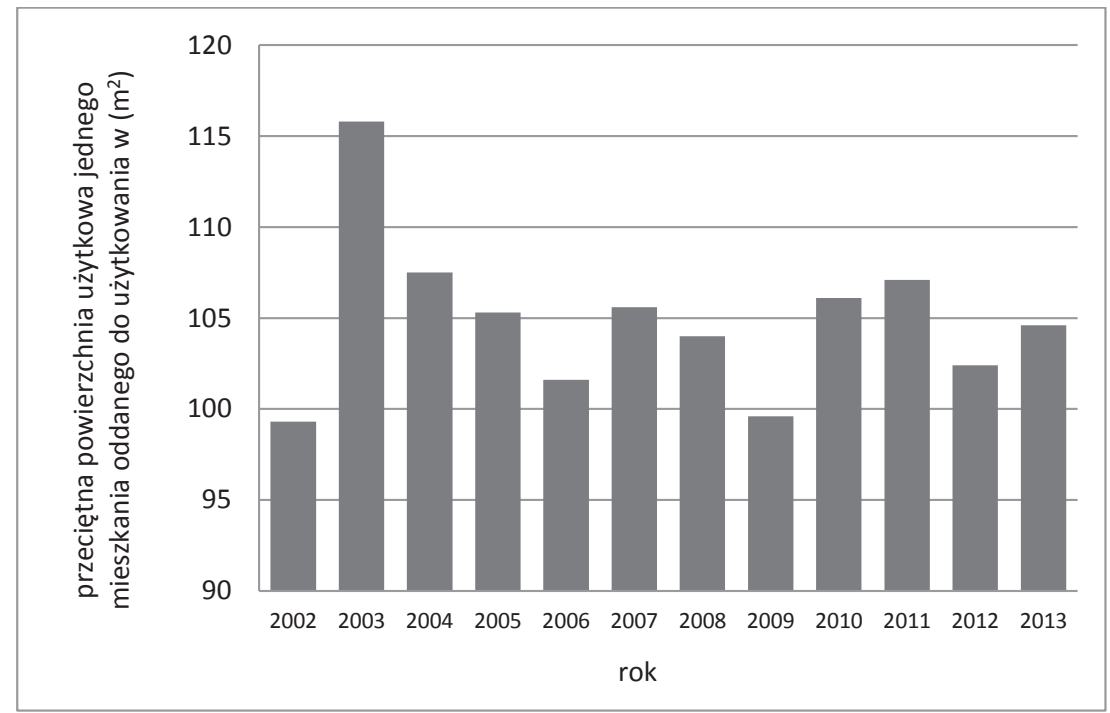

Źródło: opracowanie własne na podstawie Banku Danych Lokalnych GUS 
Przeciętna powierzchnia mieszkania przypadająca na osobę wzrosła w ostatnim dziesięcioleciu z 22 do ponad $26 \mathrm{~m}^{2}$. Mimo że poziom przepełnienia mieszkań w naszym kraju systematycznie się zmniejsza, daleko Polakom do zadowolenia w tym aspekcie. Tym bardziej, że zmniejszenie to (wyrażone przez wzrost zasobu mieszkaniowego na 1000 osób bądź wzrost przeciętnej powierzchni użytkowej mieszkania na osobę albo spadek przeciętnej liczby osób w lokalu) nastąpiło w znacznym stopniu nie tylko dzięki rosnącej liczbie mieszkań oddawanych do użytkowania, ale także na skutek negatywnych zjawisk demograficznych, czyli spadku liczby małżeństw oraz emigracji zagranicznej Polaków. Jednocześnie trudno jednoznacznie stwierdzić systematyczny wzrost powierzchni mieszkań oddawanych do użytkowania. Korzystny w tym zakresie był 2003 rok, tuż przed przystąpieniem Polski do Unii Europejskiej, gdy przeciętne mieszkanie oddane do użytkowania miało blisko $116 \mathrm{~m}^{2}$. W kolejnych latach notowano wahania tego wskaźnika, ze szczególnie niekorzystną wartością w 2009 roku (niespełna $100 \mathrm{~m}^{2}$ ). Aktualnie jest to ok. $105 \mathrm{~m}^{2}$, czyli de facto niewiele więcej niż kilkanaście lat temu, kiedy to średnia wielkość mieszkania oddawanego do użytkowania wynosiła poniżej $100 \mathrm{~m}^{2}$ (ryc. 9).

Warunki mieszkaniowe mierzone liczbą mieszkań przypadających na 1000 mieszkańców w Polsce są zróżnicowane regionalnie. Wskaźnik ten jest zdecydowanie najkorzystniejszy w województwach mazowieckim i łódzkim, gdzie wynosi blisko 400. Najgorzej sytuacja wygląda w województwach najbardziej zaludnionych, tam gdzie w przeszłości występowało spore przeludnienie agrarne, czyli w województwach podkarpackim (299) i małopolskim (332), chociaż dotyczy również województwa wielkopolskiego (332) (tab. 6).

Tab. 6. Liczba mieszkań przypadająca na 1000 mieszkańców w Polsce według województw w latach 2003-2013

\begin{tabular}{|c|c|c|c|c|c|c|c|c|c|c|c|}
\hline \multirow{3}{*}{ Województwo } & \multicolumn{11}{|c|}{ Liczba mieszkań na 1000 mieszkańców } \\
\hline & \multicolumn{11}{|c|}{ rok } \\
\hline & 2003 & 2004 & 2005 & 2006 & 2007 & 2008 & 2009 & 2010 & 2011 & 2012 & 2013 \\
\hline łódzkie & 363 & 365 & 368 & 371 & 374 & 378 & 381 & 384 & 387 & 391 & 395 \\
\hline mazowieckie & 357 & 360 & 364 & 367 & 371 & 377 & 383 & 392 & 395 & 399 & 402 \\
\hline małopolskie & 308 & 310 & 312 & 315 & 318 & 322 & 327 & 323 & 325 & 329 & 332 \\
\hline śląskie & 352 & 355 & 357 & 360 & 363 & 366 & 368 & 366 & 369 & 371 & 375 \\
\hline lubelskie & 316 & 319 & 322 & 325 & 328 & 332 & 335 & 336 & 340 & 344 & 348 \\
\hline podkarpackie & 284 & 285 & 287 & 289 & 291 & 293 & 295 & 291 & 293 & 296 & 299 \\
\hline podlaskie & 327 & 330 & 333 & 336 & 340 & 344 & 348 & 349 & 353 & 358 & 362 \\
\hline świętokrzyskie & 318 & 320 & 323 & 325 & 327 & 330 & 332 & 332 & 335 & 338 & 341 \\
\hline lubuskie & 326 & 328 & 331 & 334 & 337 & 341 & 344 & 343 & 346 & 349 & 352 \\
\hline wielkopolskie & 305 & 307 & 309 & 311 & 314 & 317 & 320 & 323 & 325 & 329 & 332 \\
\hline zachodniopomorskie & 334 & 337 & 339 & 342 & 346 & 350 & 354 & 356 & 359 & 363 & 366 \\
\hline dolnośląskie & 345 & 347 & 350 & 354 & 357 & 361 & 366 & 368 & 371 & 376 & 382 \\
\hline opolskie & 315 & 317 & 319 & 322 & 325 & 328 & 330 & 338 & 341 & 343 & 347 \\
\hline kujawsko-pomorskie & 321 & 322 & 324 & 326 & 328 & 332 & 335 & 335 & 338 & 341 & 345 \\
\hline pomorskie & 322 & 325 & 327 & 331 & 334 & 339 & 343 & 343 & 347 & 351 & 355 \\
\hline warmińsko-mazurskie & 315 & 318 & 321 & 324 & 328 & 332 & 335 & 332 & 336 & 340 & 344 \\
\hline Polska & 330 & 332 & 335 & 338 & 341 & 345 & 349 & 350 & 353 & 356 & 360 \\
\hline
\end{tabular}

Źródło: opracowanie własne na podstawie Banku Danych Lokalnych GUS 
Przeciętna powierzchnia użytkowa mieszkania na jedną osobę wynosi w Polsce zaledwie 26,3 $\mathrm{m}^{2}$ (2013) (ryc. 8 i 10). Jedynie siedem województw ma wskaźnik powyżej tej wartości, są to województwa: mazowieckie $(28,8)$, opolskie $(27,8)$, dolnośląskie $(27,5)$, podlaskie $(27,4)$, łódzkie $(26,9)$, wielkopolskie $(26,7)$ i lubelskie $(26,6)$. Zdecydowanie najgorsza sytuacja dotyczy trzech województw: podkarpackiego $(24,0)$, kujawsko-pomorskiego $(23,8)$ i warmińsko-mazurskiego $(23,3)$ (ryc. 10).

Ryc. 10. Przeciętna powierzchnia użytkowa mieszkania przypadająca na jedną osobę w Polsce wg województw w 2013 roku

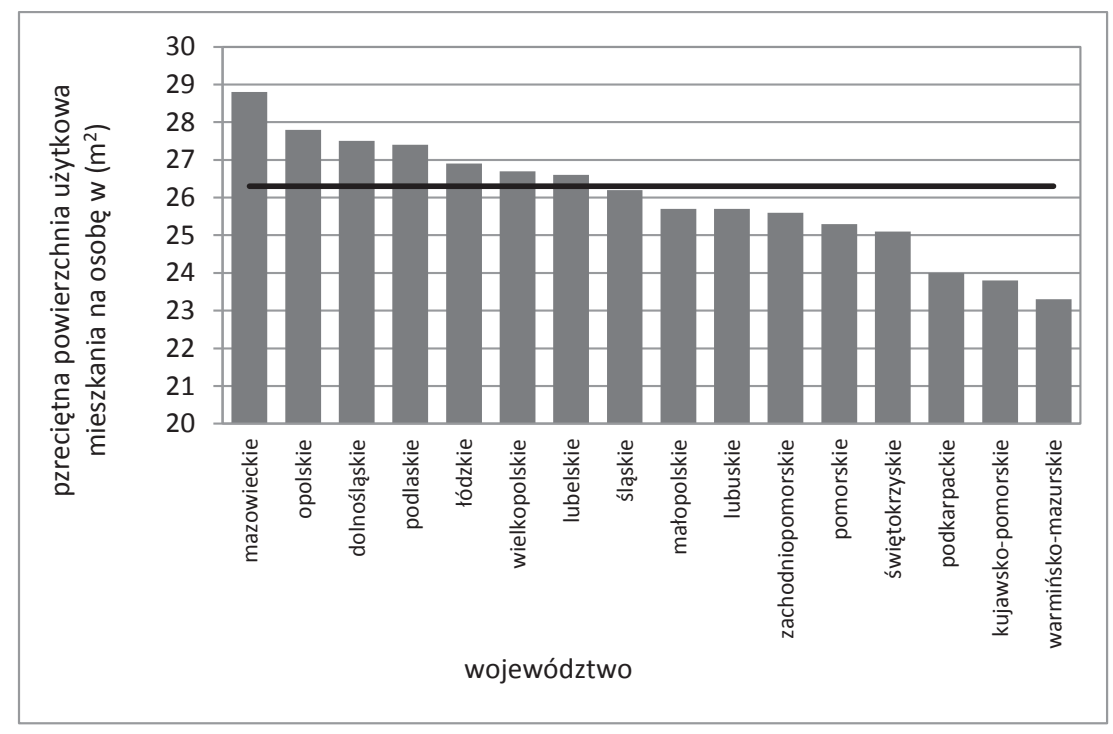

Źródło: opracowanie własne na podstawie Banku Danych Lokalnych GUS

Interesująco kształtuje się rozkład przestrzenny wartości omawianego wskaźnika dla województwa małopolskiego. Przeciętna powierzchnia użytkowa mieszkania na jedną osobę dla tego regionu wynosi zaledwie $25,7 \mathrm{~m}^{2}$ i jest niższa od średniej krajowej. Spośród 22 powiatów tylko dziewięć charakteryzuje wartość wskaźnika powyżej średniej (2013). Przy tym najwyższa wartość dotyczy powiatu tatrzańskiego $(32,1)$, gdzie występuje dodatkowy zasób powierzchni mieszkaniowej służącej jako baza noclegowa dla turystów, będącej źródłem utrzymania sporej części mieszkańców tego terenu. Następne powiaty o najwyższej wartości wskaźnika to dwa powiaty znajdujące się w bezpośrednim sąsiedztwie Krakowa: krakowski $(29,4)$ i wielicki $(29,1)$. Kolejne dwa to typowo rolnicze powiaty na północ od Krakowa: proszowicki (29) i miechowski (27,6). Co interesujące, wynik powyżej średniej wojewódzkiej uzyskało samo miasto Kraków (26,3). Dalsze trzy powiaty o wartościach wskaźnika powyżej średniej dla województwa to powiaty o charakterze wiejskim, oddalone od stolicy województwa: suski $(26,2)$, bocheński $(26,1)$ i brzeski $(25,8)$. Zdecydowanie najniższe wartości wskaźnika dotyczyły trzech powiatów w południowej części województwa, o charakterze typowo wiejskim: gorlickiego $(23,1)$, limanowskiego $(22,6)$ i nowosądeckiego $(22,0)$. Niezwykle interesujące jest dynamiczne kształtowanie się omawianego wskaźnika dla trzech 
największych miast województwa, które w okresie 2003-2013 zanotowały szczególnie wysoki wzrost przeciętnej powierzchni użytkowej mieszkania przypadającej na jednego mieszkańca. W przypadku Krakowa wartość wskaźnika wzrosła z 21 do 26,3. Dla Nowego Sącza było to odpowiednio: 21,5 i 25,6, natomiast dla Tarnowa - 20,4 i 24,1. Porównywalnie wysoki wzrost wartości wskaźnika dotyczył także powiatu tatrzańskiego: 27,1 i 32,1 (ryc. 11).

Ryc. 11. Przeciętna powierzchnia użytkowa mieszkania przypadająca na jednego mieszkańca w województwie małopolskim wg powiatów w latach 2003 i 2013

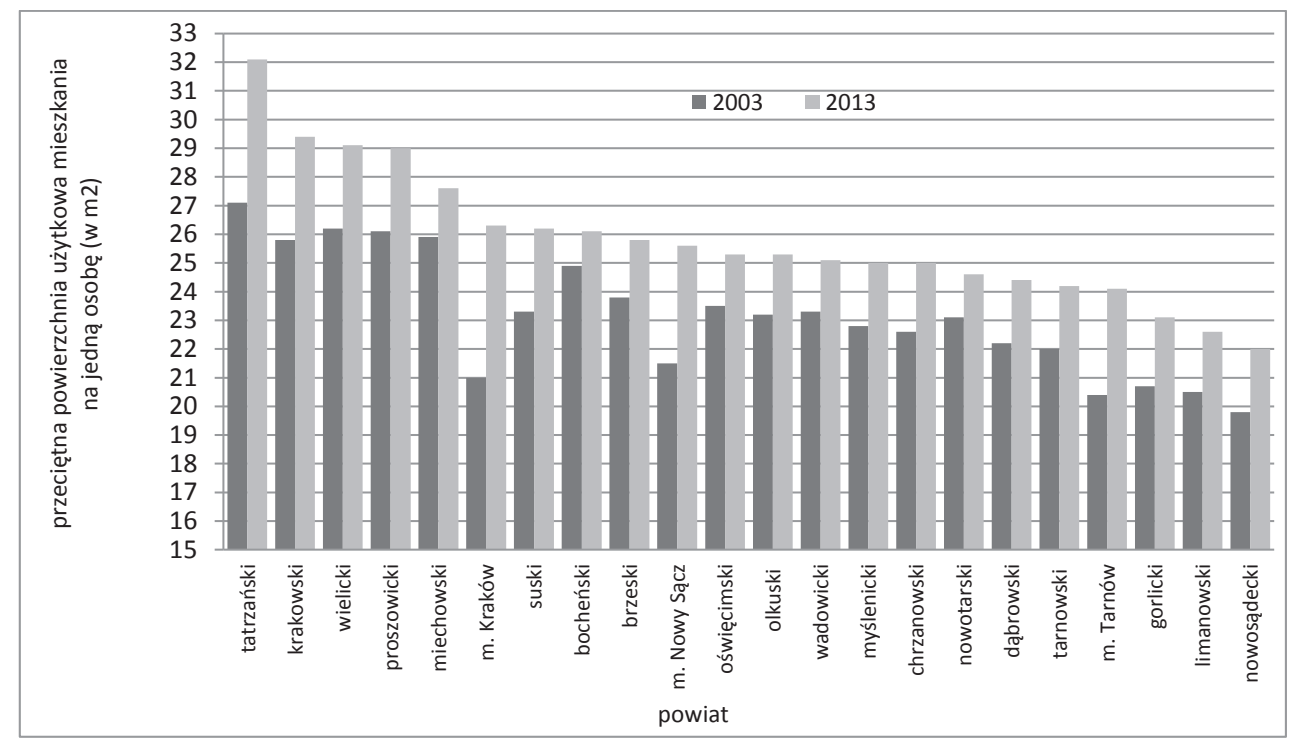

Źródło: opracowanie własne na podstawie Banku Danych Lokalnych GUS

\section{ZAKOŃCZENIE}

Sektor budowlany stanowi ważną część polskiej gospodarki, przy czym jest bardzo wrażliwy na koniunkturę gospodarczą, na którą reaguje jednak z pewnym opóźnieniem. Widoczna opóźniona reakcja na ostatni światowy kryzys gospodarczy związana była ze specyfiką omawianej branży, w której realizuje się inwestycje długoterminowe, często przyjęte do realizacji w okresie jeszcze przedkryzysowym. W warunkach światowego kryzysu gospodarczego tendencja wahań produkcji budowlano-montażowej uzyskała najbardziej niekorzystne wskaźniki w latach 2009 i 2010, czyli rok później niż w przypadku produkcji przemysłowej (2008 i 2009). Po pewnym ożywieniu i zwiększeniu produkcji budowlano-montażowej w 2011 roku spodziewano się utrzymania korzystnej tendencji, niestety kolejne lata przyniosły ponowny spadek produkcji. Nastąpiło to głównie w związku z ograniczeniem wydatków na budowę dróg i autostrad po 2012 roku. Można prognozować pewne ożywienie w produkcji budowlano-montażowej w związku z nowymi inwestycjami w energetyce - rozpoczęcie budowy nowych bloków energetycznych w Opolu i Kozienicach, jednak nie będą to inwestycje o wartości równej tym infrastrukturalnym sprzed 2012 roku. 
W odniesieniu do budownictwa mieszkaniowego, w ostatnich dwóch dekadach zanotowano znaczny przyrost mieszkań oddawanych do użytkowania, zarówno w wartościach bezwzględnych, jak też w przeliczeniu na 1000 mieszkańców lub liczbę metrów kwadratowych przypadającą na jednego mieszkańca. W ujęciu regionalnym i lokalnym zaobserwowano pewną prawidłowość, polegającą na wzmożonych inwestycjach mieszkaniowych na terenach wcześniej niedoinwestowanych. W skali Polski dotyczyło to przede wszystkim województw: świętokrzyskiego, łódzkiego, dolnośląskiego i podlaskiego. W przypadku województwa małopolskiego odnosiło się to w dużej mierze do powiatów typowo wiejskich, raczej oddalonych od dużego miasta, takich jak: miechowski, nowosądecki, bocheński, dąbrowski, jak również tych graniczących ze stolicą województwa - Krakowem, a zwłaszcza powiatu wielickiego, ale także największych miast województwa, czyli Krakowa, Tarnowa i Nowego Sącza. Jednocześnie, mimo korzystnych trendów, Polskę nadal charakteryzuje przepełnienie mieszkań ludnością - według badań Eurostatu blisko 50\% polskich mieszkań jest nadmiernie zaludnionych w porównaniu do krajów unijnych (18\%).

\section{Literatura \\ References}

Badanie ankietowe rynku pracy, Raport 2013 (2014, 20 października). NBP. Pozyskano z http://www. nbp.pl/publikacje/arp/raport_2013.pdf.

Budownictwo (2014, 21 października). Dom Maklerski BDM S.A. Pozyskano z http://www.bdm.com.pl/ Dynamika produkcji przemysłowej i budowlano-montażowej w lipcu 2014 r. (2014, 21 października). GUS. Pozyskano z http://stat.gov.pl/obszary-tematyczne/przemysl-budownictwo-srodki-trwale/ przemysl/dynamika-produkcji-przemyslowej-i-budowlano-montazowej-w-lipcu-2014-r-,5,28. html

Gorzelak, G. (2009). Geografia polskiego kryzysu. Kryzys peryferii czy peryferia kryzysu? Warszawa: Regional Studies Association - Sekcja Polska.

Housing Europe Review, The Nuts and Bolts of European Social Housing Systems 2011 (2012). Bruksela: CECODHAS Housing Europe's Observatory.

Housing Europe Review, The Nuts and Bolts of European Social Housing Systems 2012 (2013). Bruksela: CECODHAS Housing Europe's Observatory.

Kozik, R., Starzyk, E. (2011). Wpływ światowego kryzysu gospodarczego na polski rynek zamówień publicznych na roboty budowlane, Budownictwo i Inżynieria Środowiska, 2, 527-530.

Płaziak, M. (2013). Technologia tanich domów energooszczędnych jako odpowiedź na kryzys w budownictwie mieszkaniowym. Przedsiębiorczość-Edukacja, 9, 214-226.

Płaziak, M., Szymańska, A.I. (2014). Construction Sector in the Czech Republic and Poland: Focus on the Housing Segment in Selected Regions. Entrepreneurial Business and Economics Review, $2(2), 47-63$.

Rachwał, T. (2011). Wpływ kryzysu na zmiany produkcji przemysłowej w Polsce. Prace Komisji Geografii Przemystu Polskiego Towarzystwa Geograficznego, 17, 99-113.

Raport o sytuacji na rynkach nieruchomości mieszkaniowych i komercyjnych w Polsce w 2013 r. (2014). Warszawa: NBP, Departament Stabilności Finansowej we współpracy z oddziałami okręgowymi. Rocznik statystyczny pracy 2012. (2014). Warszawa: GUS.

Tarnawska, K. (2011). Analiza przydatności polityki regionalnej UE w przeciwdziałaniu negatywnym skutkom kryzysu w krótkim i długim okresie. W: Z. Dach (red.). Polityka makroekonomiczna w warunkach kryzysu i jej wptyw na gospodarkę. Warszawa: Wolters Kluwer.

Monika Plaziak, dr, adiunkt, Uniwersytet Pedagogiczny w Krakowie, Instytut Geografii, Zakład Przedsiębiorczości i Gospodarki Przestrzennej. Zainteresowania badawcze autorki dotyczą zagadnień 
gospodarki przestrzennej w kontekście czynników lokalizacji przedsiębiorstw, szczególnie czynnika personalnego. Prace badawcze odnoszą się również do zagadnień współpracy jednostek naukowych i badawczo-rozwojowych z sektorem małych i średnich przedsiębiorstw, zwłaszcza w zakresie wdrażania nowych technologii i materiałów, w tym dotyczących budownictwa energooszczędnego i pasywnego. Ponadto autorka zajmuje się problematyką poziomu i jakości życia ludności, ze szczególnym uwzględnieniem małych i średnich miast Polski oraz miast postsocjalistycznych.

Monika Plaziak, Ph.D., assistant professor in the Department of Entrepreneurship and Spatial Management, Institute of Geography, Pedagogical University of Cracow. Author's research interests concern issues of the spatial development in the context of location factors of enterprises, especially personal factor. Research works also refer to issues of the cooperation of scientific and research-developmental organizations with the sector of small and medium-sized enterprises, especially in the matter of the implementing new technologies and materials concerning the energy-efficient and passive building. Additionally, the author analyses issues of the level and quality of life, with particular reference to small and medium-sized towns in Poland, and post socialist towns.

Anna Irena Szymańska, dr, adiunkt, Uniwersytet Pedagogiczny w Krakowie, Instytut Geografii, Zakład Przedsiębiorczości i Gospodarki Przestrzennej. Absolwentka studiów na kierunku zarządzanie i marketing Uniwersytetu Ekonomicznego w Krakowie, doktor nauk ekonomicznych w zakresie nauk o zarządzaniu (Katedra Analizy Rynku i Badań Rynkowych - Uniwersytet Ekonomiczny w Krakowie). Adiunkt w Zakładzie Przedsiębiorczości i Gospodarki Przestrzennej Uniwersytetu Pedagogicznego w Krakowie. Zainteresowania badawcze oscylują wokół problematyki potrzeb, preferencji i zachowań rynkowych konsumentów, jak również zagadnień z obszaru przedsiębiorczości i innowacyjności przedsiębiorstw, ze szczególnym uwzględnieniem sektora MŚP.

Anna Irena Szymańska, Ph.D., assistant professor in the Department of Entrepreneurship and Spatial Management, Institute of Geography, Pedagogical University of Cracow. Graduated the University of Economics in Krakow, MA degree in Management and Marketing, PhD degree in economic sciences in the field of management sciences (Chair of Market Analysis and Marketing Research - University of Economics in Krakow). Adjunct in the Department of Entrepreneurship and Spatial Management at Pedagogical University of Krakow. Her research interests are related to the issue of consumer needs, preferences and market behaviour as well as issues in the area of entrepreneurship and innovation with particular emphasis on the SME sector.

\section{Adres/address:}

Uniwersytet Pedagogiczny w Krakowie

Instytut Geografii

Zakład Przedsiębiorczości i Gospodarki Przestrzennej

ul. Podchorążych 2, 30-084 Kraków, Polska

e-mail:mplaziak@up.krakow.pl (Monika Płaziak)

e-mail: aszym@up.krakow.pl (Anna Irena Szymańska) 